\title{
鼾患者に拈ける睡眠時無呼吸の発生頻度
}

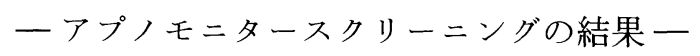

吉田 瑞生・朝倉 光司・新谷 朋子・形浦 昭克

\section{Prevalence of Sleep Apnea Syndrome in Patients Complaining of Snoring and/or Sleep Apnea}

\author{
Mizuki Yoshida, Kohji Asakura, Tomoko Shintani and Akikatsu Kataura \\ (Sapporo Medical University)
}

\begin{abstract}
Three hundred and ninety-three patients (292 male and 101 female) who visited our clinic complaining of snoring and/or apnea during sleep were evaluated for sleep apnea syndrome (SAS) by Apnomonitor screening. A total of 131 patients (114 male and 17 female) showed an apnea index (A.I.) higher than 10 apnea episodes/hour, and there was a significant correlation of the A.I. with age, sex, and body mass index (BMI) in these patients. All patients with severe SAS (more than 50 apnea episodes/hour) were men, who had a BMI greater than 25, with the exception of 1 patient. Significantly higher ages and BMI were found to exist in patients with SAS than in those without SAS.
\end{abstract}

Key words : sleep apnea, snoring, apnomonitor, screening

\section{はじめに}

睡眠時無呼吸症候群 (sleep apnea syndrome) は, 睡眠 時に呼吸が障害され，日中の強い眠気や集中力低下を認 めたり, 呼吸器, 循環器等への影響が指摘されている. 現在では徐々に一般の人々にも認知され，精查目的で受 診する数も増加してきて扣り, 注目を集めている疾患と 考号れる，当科ではいびき，睡眠時無呼吸を主訴とす る患者に対し，睡眠時無呼吸症候群のスクリーニングと してアプノモニターを用いている。中高齢の肥満男性に 多いとされているいびき患者や睡眠時無呼吸症候群患者 の現状について，多数症例に淤けるアプノモニターの検 查結果より統計的検討を行った.

\section{対象および方法}

1988年 1 月から1994年11月までに，いびきや睡眠時無 呼吸を主訴札榥医科大学附属病院耳鼻咽喉科外来を受
診した患者のらちアプノモニターを施行した393例(男性 292例，女性101例)を対象に検討を行った，平均年齢 $45.4 \pm 1.0$ 歳(男性 $46.4 \pm 1.1$ 歳, 女性 $42.6 \pm 2.1$ 歳) であ った。

スクリーニングにはアプノモニターMAY-715（チェ スト社製)を用いた。これは在宅でも実施できるように 開発された簡易型睡眠時呼吸モニター1)で，睡眠時無呼 吸症候群の精査に用いるレスピグラム2)3) と高い相関を 持つとされている。モニター項目は 1$)$ サーミスターに よる鼻気流，2)小型マイクロフォンによる気管音，3) 心電図の 3 チャンネルである. 鼻気流は外鼻孔の入口に 装着したサーミスターにて検出し，気管音は甲状軟骨よ り 1 2 cm 下の皮膚上に装着した小型マイクロフォン にて検出する。このように取り込まれた呼吸情報は, 気 管音扣よび鼻気流とも閾値以下の信号が 10 秒以上続くと 無呼吸として認識される。また心電図は R-R 間隔の10 
秒間ごとの平均值を記憶し，心拍数をモニターすること ができる。これらの記憶した情報は，ICメモリーに記 録し, 後にコンピューター解析して無呼吸発作状況, 無 呼吸発作継続時間のヒストグラム, 心拍数のトレンド表 示を示すことが可能である。この結果よりいびき患者と 病的無呼吸患者の性別, 年齢分布拈よび肥満度と無呼吸 指数との相関について検討した.また性別，年齢別，肥 満度別に抢ける無呼吸指数の有意差について子検討した。 無呼吸指数(一夜の睡眠中に扝ける 1 時間あたりでの無 呼吸回数, apnea index, 以下 A.I. と略す)が10以上を 病的無呼吸とし，そのうち 10 以上 30 未満を軽症, 30 以上 50 未満を中等症，50以上を重症と分類した．以下ょり今 回の対象患者をいびき患者, 無呼吸指数 10 以上の患者を 病的無呼吸患者, 無呼吸指数10未満の患者を習慣性いび き症患者と表現する。また肥満度の評価として体重 $(\mathrm{kg})$ を身長 $(\mathrm{m})$ の 2 乗で除した值である BMI (body mass index) を用いた。一般に BMI は20未満はやせ，20〜24が 普通，24〜26.4が太り気味，26.4以上を太りすぎと判定 するとされて和り，今回 BMI 25 以上を肥満として検討 した。

\section{結 果}

いびき患者の性別执よび年齢分布は図 1 亿示すように 10歳未満と $40 ６ 0$ 歳代にピークを認めた。 また 20 歳代の 久女性患者数が男性数を越えた。

いびき患者全体の平均無呼吸指数は $10.2 \pm 0.7 て ゙$, 病 的無呼吸患者は，131例，33.3\% 亿認めた(表 1)。平均
表 1 対象者の結果

\begin{tabular}{lcccc}
\hline \hline & $\mathrm{n}$ & A.I. $\geqq 10$ & A.I. $<10$ & 平均 A.I. \\
\hline 全症例 & 393 & 131 & 262 & $10.2 \pm 0.7$ \\
男 性 & 292 & 114 & 178 & $11.7 \pm 0.8$ \\
女 性 & 101 & 17 & 84 & $5.6 \pm 0.8] * *$ \\
& & & & $* * \mathrm{p}<0.01$
\end{tabular}

無呼吸指数は男性 $11.7 \pm 0.8$, 女性 $5.6 \pm 0.8$ であり, 男 女間では危険率 $1 \%$ 以下 $(\mathrm{p}<0.01)$ で男性で無呼吸指数 が高いとの結果を得た。また無呼吸指数10以上は男性の 114名 (39.0\%)，女性の17名(16.8\%)で男性に执忷る頻 度は女性の 2 倍以上であった. 特に無呼吸指数50以上の 重症例はすべて男性であった(表 1，2).

患者年齢別に病的無呼吸の頻度をみると，高年齢にな る程病的無呼吸を示す患者の割合が多くなる傾向を認め

表 2 無呼吸指数 50 以上の重症例

\begin{tabular}{clccl}
\hline \hline 症例 & A.I. & 年齡 & 性別 & BMI \\
\hline 1 & 50.4 & 50 & 男 & 28.3 \\
2 & 50.5 & 39 & 男 & 24.2 \\
3 & 52.2 & 51 & 男 & 27.6 \\
4 & 52.9 & 39 & 男 & 37.2 \\
5 & 57.7 & 34 & 男 & 28.3 \\
6 & 58 & 50 & 男 & 30.8 \\
7 & 63.3 & 53 & 男 & 35.8 \\
8 & 71 & 31 & 男 & 26
\end{tabular}

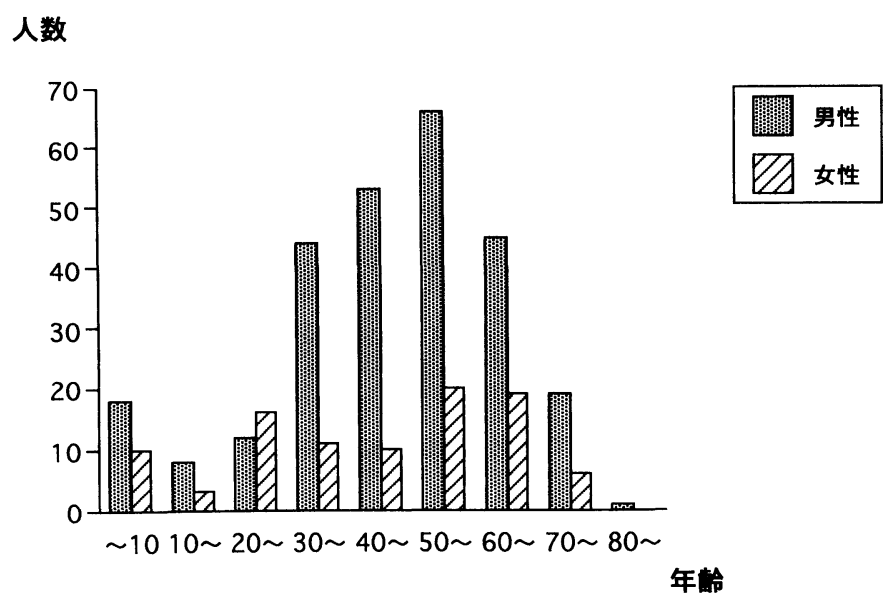

図1 対象者の各年代に括ける人数 


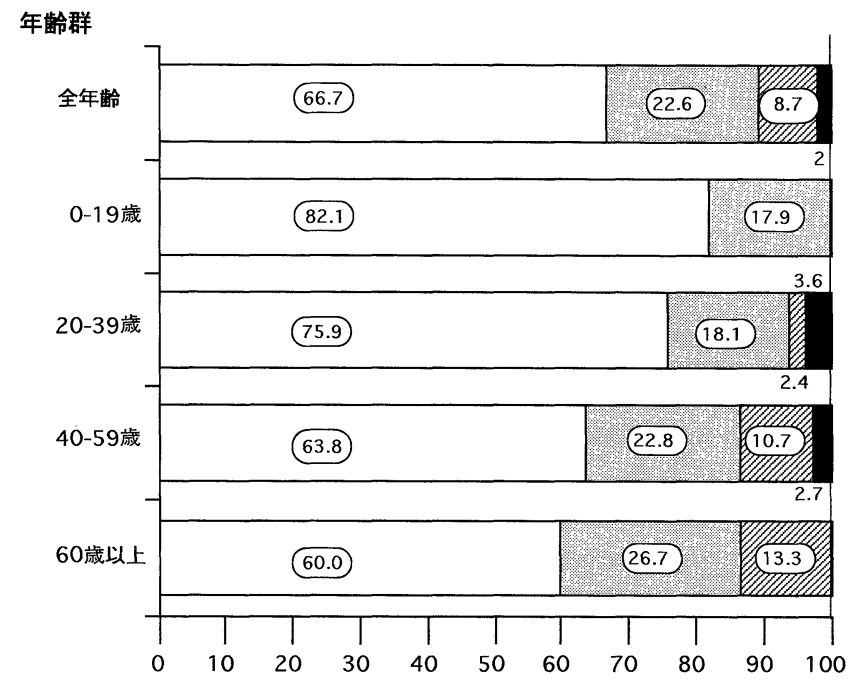

(\%)

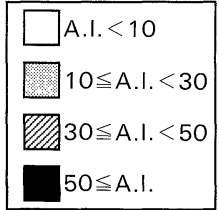

図 2 各年齢群における重症度別の割合

表 3 無呼吸指数による重症度分類

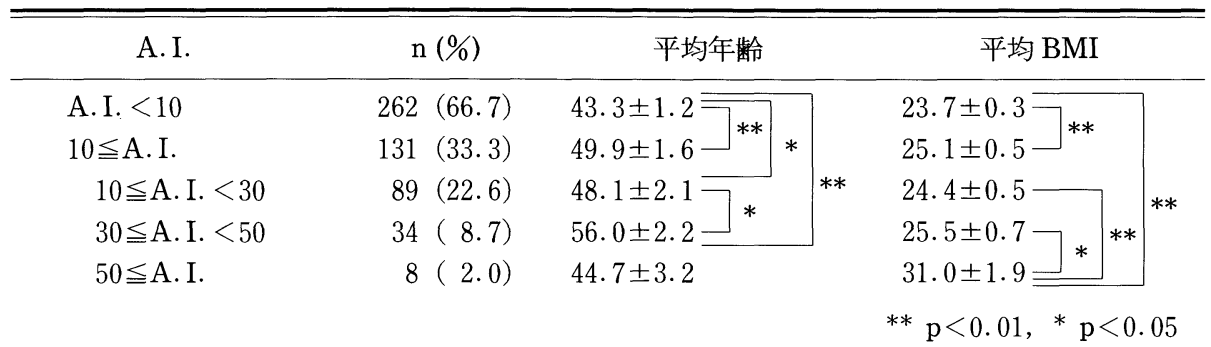

た（図 2 ）。また，無呼吸の重症度別に患者の平均年齢を みると,やはり病的無呼吸群で高くなる傾向を認めた(表 3 ).

無呼吸重症度と肥満程度との関連性に関しては, BMI が25未満の非肥満群の平均無呼吸指数は $7.2 \pm 0.7$ であり, BMI 25 以上の肥満群では $12.7 \pm 1.3$ で有意差 を認めた $(\mathrm{p}<0.0001)$ (図 3 )。 。た，重症な無呼吸群注 ど BMI が高值を示し(表 3 ), 無呼吸指数と肥満度 BMI とは有意な正の相関を示した（いびき患者全体， $\mathrm{r}=0.225, \mathrm{p}<0.0001$, 病的無呼吸患者, $\mathrm{r}=0.34, \mathrm{p}<$ 0.0001 )（図 4 ).

\section{考察}

睡眠時無呼吸症候群は小児ではアデノイド，口蓋扁桃 肥大が主な原因，増悪因子とされている一方，成人では

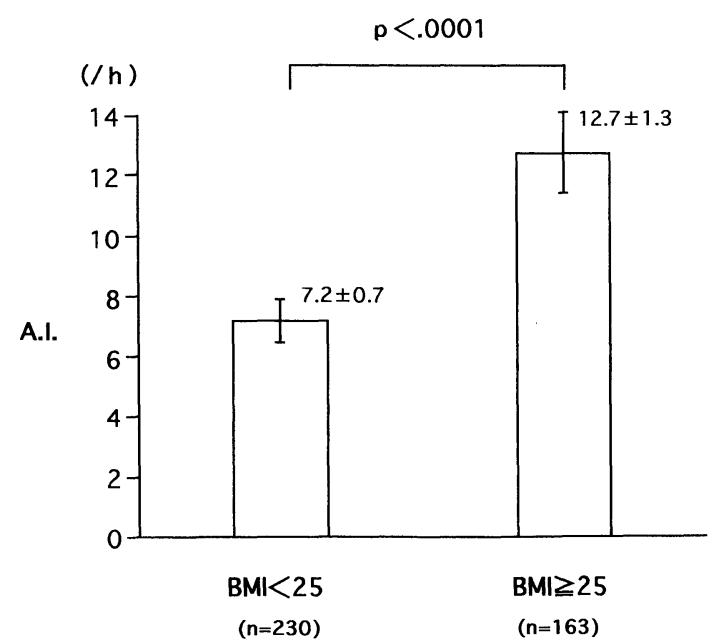

図 3 肥満度別による無呼吸指数との関係 


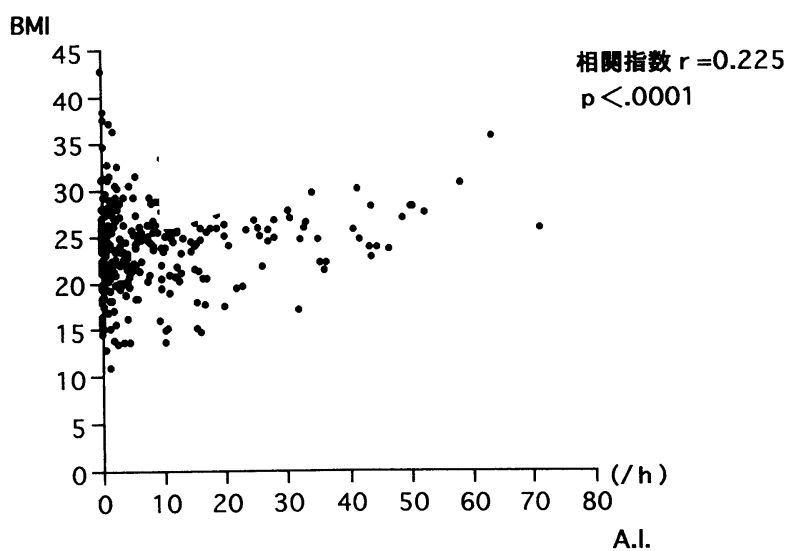

図 4 無呼吸指数と BMI の関係

いびさ, 肥満を伴い呼吸, 循環障害の関与も重要視され てきている.今回いびきや睡眠時無呼吸を主訴に当科外 来を受診し，アプノモニターを用いて外来的に睡眠時無 呼吸のスクリーニングを施行した患者を対象に検討した。

今回の検討では $\mathrm{AI} \geqq 10$ の病的無呼吸は，33.3\%の患 者に認められた. 男女別にみると, 男性の $39.0 \%$ に対し て女性の $16.8 \%$ と男性が 2 倍以上の有病率を示し, 特に $\mathrm{AI} \geqq 50$ の重症例はすべて男性であった(表 2 ). Viner $5^{4)}$, Young ら5) の海外の報告をみても同様に男性に多 い傾向を認めているが，その原因に関しては不明である。 また唯一20代では女性の方が男性より患者数が多い。こ れは結婚や旅行に伴ら周囲への迷惑の心配が受診の理由 とされるためだが，実際に病的無呼吸を認めた 17 名中 2 名が20代女性でらち 1 名は BMI 36.2 の高度肥満であっ た. 病的無呼吸を有する女性の多くが40〜 70歳代で，他 の報告677) 同様更年期以降の年代に多く認め, ホルモン や肥満の影響が示唆される.

今回，いびき患者における病的無呼吸の頻度をみた結 果，中高年までは年齢とともに病的無呼吸患者の割合が 高くなる傾向を認めた. Young ら5) も AHI (apnea hypopnea index) が 5 以上の睡眠時無呼吸症候群は男女と も年齢とともに増加し，40歳代が最も高頻度であると報 告している. 病的無呼吸患者群 (44例)で若年症例ほど無 呼吸回数が多い傾向があるとの報告もあるが8)，睡眠時 無呼吸症候群症例の年齢分布をみると中高齢層に多く集 中し, 高齢者ほど睡眠時無呼吸の頻度の増加を認めると する報告が多い9). これには加齢による生理的変化とし ての睡眠中の無呼吸, 低換気の頻度の増加の影響も示唆
されている. 今回の検討でも 60 歳以上の群に重症例はな かったことより，高㱓になるほど生理的に無呼吸の頻度 は増えるが必ずしもより重症となるとはい壳ず，実際の 睡眠時無呼吸症候群のピークは中高年齢層であると考光 られる。な敃年齢的要素による生理的な無呼吸の増加も 考慮すると，高齢者に括ける無呼吸指数の正常值の決定 は困難であるとの意見もみられている9 .

今回の結果では BMI と無呼吸指数との相関も認め, 肥満例と非肥満例間での無呼吸指数に有意差を認めた. 肥満と睡眠時無呼吸との関係について, 肥満度の指標に BMI の他, ブロカ指数や理想体重を用い, これと無呼 吸指数の相関を認めたといら報告もある410). その一方 で肥満度について睡眠時無呼吸症候群と単純躳症との間 に有意差を認めるが, 肥満度と無呼吸指数の相関を認め ない報告 ${ }^{11)} や ，$ 肥満度と無呼吸指数との相関は認める が, 睡眠時無呼吸症候群の半数 (44例中22例) が非肥満例 であり, 肥満群と非肥満群の間で無呼吸指数との比較検 討で有意差を認めない報告もある ${ }^{8)}$. 確かに肥満である が軽症である症例もあり, 肥満が睡眠時無呼吸症候群の 唯一の発症要因とは言及でさないが強い関連があると思 われる. その背景に肥満に伴う体重増加, 体型の変化, 咽喉頭支持組織の脂肪沈着による気道狭窄や胸郭のコン プライアンス低下などの形態学的異常が閉塞型睡眠時無 呼吸症候群の重症化に関与していることが考えられる.

しかし肥満により, 睡眠時無呼吸症候群のリスクが高 まるのは，単に形態学的異常のみではなく，低酸素状態 による交感神経充進や呼吸中枢の機能異常も指摘されて きている12). 最近睡眠時無呼吸の測定と同時にパルスオ キシメーターにより経皮的に血液中酸素飽和度もモ二 ターできる簡易型睡眠時呼吸モニターが出現した．この 易操作性によって成人病との関連があるとされているこ の症候群の呼吸, 循環障害への関与などに関する疫学的 検討に有用となることが期待できる.

成人に拉けるX線像による頭蓋骨顔面の計測より, 睡 眠時の無呼吸回数が多い注ど上顎と下顎の突出が不良で, 舌骨が下方に変位していると報告13)されている。した がって，肥満のない無呼吸症候群患者では顔面頭蓋骨の 条件も考慮に入れる必要がありそらである。

睡眠時無呼吸症候群の頻度や危険因子に関し, Viner ら 4) は睡眠時無呼吸症候群疑いの410名に問診とポリソ ムノグラフィーから, 年齢, BMI, 男性, いびきが予测 可能因子と報告している. 今回の検討結果でも，いびき 
を伴ら患者, 特に中高年の肥満男性では睡眠時無呼吸症 候群を疑い，治療を要する重症例を見逃さないためにも 積極的に精査を考慮すべきと考える.

\section{結 論}

いびき，睡眠時無呼吸を主訴とする患者393名に施行 したアプノモニターの結果を統計的検討したところ， 131名 (33.3\%) が無呼吸指数 10 以上であった. またいび き患者に拈いて病的無呼吸を示寸割合は, 性別, 年齢, 肥満度に左右される傾向を認めた。

本論文の要旨は第171回日本耳鼻咽喉科学会北海道地方部会 で口演した。

\section{参考文献}

1) 岡部慎一, 飛田 渉, 三木 祐, 他 : 在宅睡眠呼吸モ二タ一 装置の開発と臨床応用. 臨床モニター 1:463〜 470, 1990.

2 ) 中野勇治, 朝倉光司, 新谷朋子, 他：睡眠時無呼吸症のス クリーニング．耳鼻臨床 $82: 1125 \sim 1130,1989$.

3 ）宇留間善之, 西村忠郎, 森島夏樹, 他：睡眠時呼吸モ二ター 検查の有用性についてーレスピソムノグラフとアプノモ ニターの比較一. 耳鼻臨床 補65 : 113 119, 1993.

4) Viner S, Szalai JP and Hoffstein V: Are histiry and physical examination a good screening test for sleep apnea? Ann Intern Med $115:$ 356 239, 1991.

5 ) Young T, Palta M, Dempsey J, et al : The occurrence of sleep-disordered breathing among middle-aged adults. N Engl J Med 328 : 1230 1235, 1993.

6 ) Guilleminault C, Quera-Salva MA, Partinen M, et al : Women and the obstructive sleep apnea syndrome. Chest $93: 104 \sim 109,1988$.

7 ) Sandblom RE, Matsumoto AM, Schoene RB, et al : Obstructive sleep apnea syndrome induced by testosyerone administration. N Engl J Med 308 : 508 510, 1983.

8 ）倉科桂司, 佐々木厳, 大塚健造, 他: 睡眠時無呼吸症候群 のリスクファクターの検討. 日気食会報 $42: 20 \sim 26,1991$.

9 ) 岡田 保, 粥川裕平, 早河敏治, 他 : 睡眠時無呼吸症候群 一疫学, 病態, 診断の最近の進歩一. 神経進歩 $39: 149$ 163, 1995.

10）香取公明, 高安劭次, 香取早苗：鼾患者の統計的観察. 耳 鼻臨床 $87: 1563 \sim 1572,1994$.

11）角由紀子，林 理香：9 章 大阪医大耳鼻咽喉科に执ける 睡眠時呼吸障害の現況. 睡眠時呼吸障害 一その診断と治 療一(高橋宏明編). 311 323頁, 金芳堂, 京都, 1993.

12）田代哲男：睡眠時呼吸障害に関連した循環器障害. 呼吸と 循環 $42: 763 \sim 770,1994$.

13）朝倉光司，中野勇治，新谷朋子，他：閉塞型睡眠時無呼吸 症候群者に括ける頭部 X線写真上の顔面頭蓋骨計測値の検 討. 耳喉頭頸 $62 ： 997 \sim 1001,1990$.

/原稿受付：平成 9 年 9 月 8 日 原稿採択：平成 9 年10月15日 別刷請求先 : 吉田瑞生

产060-0061 札幌市中央区南 1 条西 $16 丁$ 目 